\title{
D-Xylose Utilization by Saccharomyces cerevisiae
}

\author{
By CARINA VAN ZYL, * BERNARD A. PRIOR, \\ STEPHANUS G. KILIAN AND JOHAN L. F. KOCK \\ Department of Microbiology, University of the Orange Free State, PO Box 339, \\ Bloemfontein 9300, South Africa
}

(Received 10 May 1989; accepted 14 August 1989)

\begin{abstract}
Although it is generally accepted that Saccharomyces cerevisiae is unable to assimilate D-xylose, four strains were found to utilize xylose aerobically at different efficiencies in the presence of a mixture of substrates. The degree of D-xylose utilization by $S$. cerevisiae ATCC 26602 depended upon the presence of other substrates or yeast extract. The greatest amount of xylose (up to $69 \%$ over $7 \mathrm{~d}$ ) was utilized when sugar substrates such as D-ribose were co-metabolized. Much lower degrees of utilization occurred with co-metabolism of organic acids, polyols or ethanol. A mixture of D-glucose, D-ribose, D-raffinose, glycerol and D-xylose resulted in greater xylose utilization than the presence of a single substrate and xylose. The absence of growth on a co-substrate alone did not prevent the utilization of xylose in its presence. Xylose was co-metabolized with ribose under anaerobic conditions but at a much slower rate than under aerobic conditions. When $\left[{ }^{14} \mathrm{C}\right]$ xylose was utilized in the presence of ribose under anaerobic conditions, the radioactive label was detected mainly in xylitol and not in the small amounts of ethanol produced. Under aerobic conditions the radioactive label was distributed between xylitol $(91.3 \pm 0.8 \%), \mathrm{CO}_{2}(2 \cdot 6 \pm 2.3 \%)$ and biomass $(1 \cdot 7 \pm 0.6 \%)$. No other metabolic products were detected. Whereas most xylose was dissimilated rather than assimilated by $S$. cerevisiae, the organism apparently possesses a pathway which completely oxidizes xylose in the presence of another substrate.
\end{abstract}

\section{INTRODUCTION}

According to the taxonomic literature, Saccharomyces cerevisiae lacks the ability to utilize D-xylose for growth (Kreger-van Rij, 1984). Consequently, S. cerevisiae has not been investigated extensively in the search for xylose-fermenting yeasts. Pichia stipitis, Candida shehatae and Pachysolen tannophilus are the most promising yeasts for ethanol production from hemicellulose hydrolysate (du Preez \& Prior, 1985; Watson et al., 1984b). However, the poor ethanol tolerance and slow fermentation rates of these yeasts in comparison with $S$. cerevisiae will probably limit their commercial application (du Preez et al., 1987; Watson et al., 1984b). The failure of $S$. cerevisiae to utilize D-xylose has been ascribed to its inability to convert xylose to xylulose (Gong et al., 1981). According to other reports, however, $S$. cerevisiae produces all the enzymes necessary for xylose utilization. Xylose transport in $S$. cerevisiae occurs by facilitated diffusion using the glucose uptake system (Cirillo, 1968; Kleinzeller \& Kotyk, 1967; Kotyk, 1967). Low activities of xylose reductase (XR) and xylitol dehydrogenase (XD) have also been detected in $S$. cerevisiae, indicating that it has the potential to convert xylose to xylulose via xylitol (Batt et al., 1986). Xylulose is utilized by a large number of $S$. cerevisiae strains (Ueng et al., 1981; Gong et al., 1981).

\footnotetext{
Abbreviations: XD, xylitol dehydrogenase; XR, xylose reductase; YEP, yeast extract/peptone/salts; YNB, yeast nitrogen base.
} 
Hsiao et al. (1982) suggested that $S$. cerevisiae can catabolize xylose in combination with other substrates, including glucose, xylulose and xylitol. Batt et al. (1986) have shown that xylose can be taken up and utilized in the presence of galactose.

The objective of this study was to examine the ability of $S$. cerevisiae strains to utilize D-xylose and to elucidate the properties of D-xylose utilization in strain ATCC 26602. The disappearance of xylose from the medium will subsequently be termed xylose utilization.

\section{METHODS}

Organisms. Saccharomyces cerevisiae strains were obtained from the American Type Culture Collection (ATCC cultures), Centraal Bureau voor Schimmelcultures (CBS cultures) Delft, The Netherlands and Professor J. P. van der Walt, Pretoria, South Africa (CSIR-Y cultures). The yeasts were routinely maintained on yeast-malt (YM) agar slants (Wickerham, 1951). The identity of the strains was confirmed by conventional classification methods (Barnett et al., 1983) and long-chain fatty acid composition (Kock et al., 1985).

Inoculum preparation. The inoculum was prepared by two different methods: (a) growth on fresh YM slants was suspended in sterile distilled water to an optical density equivalent to $200 \mathrm{Klett}$ units $(640 \mathrm{~nm}$; Klett-Summerson colorimeter) and $1 \mathrm{ml}$ was used to inoculate $30 \mathrm{ml}$ of medium; $(b)$ for evaluation of xylose utilization by $S$. cerevisiae ATCC 26602 a $48 \mathrm{~h}$ culture was transferred to medium containing $10 \mathrm{~g}$ glucose $\mathrm{l}^{-1}$ and $6.7 \mathrm{~g}$ yeast nitrogen base (YNB) $1^{-1}$. The culture was incubated aerobically at $30^{\circ} \mathrm{C}$ until it reached an optical density of $1.0(640 \mathrm{~nm} ; \mathrm{LKB}$ spectrophotometer) in the mid-exponential growth phase $(100 \mathrm{ml}$ medium yielded $0.05 \mathrm{~g}$ cells). The cells were harvested aseptically by centrifugation $(2500 \mathrm{~g}$ for $5 \mathrm{~min}$ ), washed twice and resuspended in sterile water to give an initial cell concentration of 2 to $3 \mathrm{~g} \mathrm{l}^{-1}$ after inoculation. The high initial biomass concentration was used to ensure measurable utilization of xylose in the absence of growth.

Media. The culture medium was either YNB $\left(6 \cdot 7 \mathrm{~g}^{-1}\right)$ medium or yeast extract/peptone/salts (YEP) medium containing yeast extract $\left(10 \mathrm{~g} \mathrm{l}^{-1}\right)$, peptone from pepsin-digested meat $\left(5 \mathrm{~g}^{-1}\right)$ and salts as follows $\left(\mathrm{l}^{-1}\right): 1 \cdot 2 \mathrm{~g}$ $\left(\mathrm{NH}_{4}\right)_{2} \mathrm{SO}_{4} ; 0.5 \mathrm{~g} \mathrm{NaCl} ; 0.1 \mathrm{~g} \mathrm{CaCl}_{2} .2 \mathrm{H}_{2} \mathrm{O} ; 0.64 \mathrm{~g} \mathrm{MgCl}_{2} .6 \mathrm{H}_{2} \mathrm{O} ; 0.79 \mathrm{~g} \mathrm{KH}_{2} \mathrm{PO}_{4} ;$ and $3.7 \mathrm{mg} \mathrm{FeCl} 2.4 \mathrm{H}_{2} \mathrm{O}$ (Quain \& Boulton, 1987). Various carbon sources were added to a final concentration of either 5 or $10 \mathrm{~g} \mathrm{l}^{-1}$ (pH 5.5). The $\mathrm{pH}$ of media containing organic acids was adjusted to $\mathrm{pH} 6$ in order to minimize toxicity.

All chemicals were obtained from Merck except for yeast extract and YNB which were obtained from Biolab Chemicals (Pretoria, South Africa) and Difco, respectively. Concentrates of the yeast extract and peptone were heat-sterilized, whereas YNB, sugar and salt concentrates were filter-sterilized by ultrafiltration.

Yeast cultivation. The yeasts were cultivated aerobically in triplicate in either $100 \mathrm{ml}$ or 1 litre Erlenmeyer flasks containing 30 or $100 \mathrm{ml}$ of medium respectively. Some experiments were done in test-tubes containing $10 \mathrm{ml}$ of medium. The flasks were incubated at $30^{\circ} \mathrm{C}$ on an orbital shaker ( 160 r.p.m.; $27.5 \mathrm{~mm}$ throw) while the test-tubes were incubated in a slanting position at $30^{\circ} \mathrm{C}$ in an incubator oscillating at 40 oscillations $\mathrm{min}^{-1}$. Anaerobic cultivation was done in tightly sealed $25 \mathrm{ml}$ serum vials containing $20 \mathrm{ml}$ of medium. Prior to inoculation, scrubbed nitrogen gas was passed through the liquid for $15 \mathrm{~min}$ (Hungate, 1969). The vials were incubated without shaking at $30^{\circ} \mathrm{C}$.

Evaluation of growth on solid medium. YNB medium containing $5 \mathrm{~g} \mathrm{I}^{-1}$ of the carbon source as indicated and $20 \mathrm{~g}$ agar $1^{-1}$ in Petri dishes was point-inoculated from a fresh slant and incubated at $30^{\circ} \mathrm{C}$. The development of a colony at the point of inoculation was taken as evidence of the ability of the yeast to grow on a given carbon source.

Aerobic labelling experiments. Warburg flasks ( $14.5 \mathrm{ml}$ total volume) containing $2 \mathrm{ml}$ of YNB medium to which $5 \mathrm{~g} \mathrm{l}^{-1}$ each of D-[U-14 $\left.\mathrm{C}\right] x y$ lose (specific activity $7.9 \mathrm{MBq} \mathrm{mmol}^{-1}$ ) and D-ribose were added were inoculated to a final concentration of $2 \mathrm{~g} \mathrm{l}^{-1}$ with either viable or autoclaved cells and incubated on an orbital shaker (160 r.p.m.) at $30^{\circ} \mathrm{C} . \mathrm{CO}_{2}$ produced during incubation was absorbed by $0.3 \mathrm{ml}$ of $1 \mathrm{M}-\mathrm{KOH}$ in the centre well of the flask. After $3 \mathrm{~d}$ the cells were removed from the medium by centrifugation and the supernatant was analysed by highperformance liquid chromatography (HPLC). Fractions $(125 \mu \mathrm{l})$ were collected from the column eluant and the distribution of the radioactivity between the cells, $\mathrm{CO}_{2}$ and column eluant was determined.

Anaerobic labelling experiments. YNB medium $(1.8 \mathrm{ml})$ containing xylose and ribose was added to $5 \mathrm{ml}$ vials and each vial was gassed with oxygen-free nitrogen (Hungate, 1969). To each vial $7 \cdot 12 \mu \mathrm{D}-\left[\mathrm{U}-{ }^{14} \mathrm{C}\right] \mathrm{xylose}$ was added to give a specific activity of $0.79 \mathrm{MBq} \mathrm{mmol}{ }^{-1}$. The final concentration of both ribose and xylose was $5 \mathrm{~g} \mathrm{l}^{-1}$. The vials were capped and autoclaved, and then inoculated with $0.2 \mathrm{ml}$ of a $S$. cerevisiae culture to a final cell concentration of $2 \mathrm{~g} \mathrm{l}^{-1}$ and incubated at $30^{\circ} \mathrm{C}$. To trap $\mathrm{CO}_{2}$ produced during fermentation the headspace of one vial was connected to another small vial containing $0.3 \mathrm{ml} 1 \mathrm{M}-\mathrm{KOH}$. After 6 weeks the cells were separated from the medium by centrifugation. The supernatant broth was analysed by HPLC and the distribution of the radioactivity was determined as described above.

Determination of radioactivity in biomass. The perchloric acid extraction method of D'Amore et al. (1988) was used with modifications as follows: cells were harvested by centrifugation, washed twice with water, held in $1 \mathrm{ml}$ $0.58 \mathrm{M}$-perchloric acid for $12 \mathrm{~h}$ at $4{ }^{\circ} \mathrm{C}$ and separated from the broth by centrifugation at $15000 \mathrm{~g}$ for $5 \mathrm{~min}$. The 
hydrolysed cells were collected on a glass microfibre filter (Whatman GF/F), washed three times with $1 \mathrm{ml}$ icecold $0.58 \mathrm{M}$-perchloric acid and three times with $5 \mathrm{ml}$ ice-cold $70 \%(\mathrm{v} / \mathrm{v})$ ethanol. The filter was air-dried and transferred to a scintillation vial for counting.

Analytical methods. Biomass was determined gravimetrically. Cells were collected on Whatman GF/F filters, washed and the filter containing the cells was dried to constant mass at $105^{\circ} \mathrm{C}$. Ethanol was determined by gas chromatography (Watson et al., 1984a) whereas sugars and polyols were determined by HPLC (Waters). Medium components were separated on a Waters Sugarpak 1 column maintained at $85^{\circ} \mathrm{C}$ using double-distilled deionized and degassed water as eluent at a flow rate of $0.5 \mathrm{ml} \mathrm{min}^{-1}$. Radioactive samples were placed in a scintillation vial containing $8 \mathrm{ml}$ scintillation fluid (Aquagel 1: Chemlab, South Africa) and radioactivity was counted in a liquidscintillation counter (LKB RackBeta, model 1217).

\section{RESULTS}

\section{Screening of yeasts}

All the strains of $S$. cerevisiae tested utilized xylose to varying degrees in the presence of raffinose, glucose, glycerol and ribose but not in the absence of this substrate mixture (Table 1). The most extensive utilization of xylose $(74 \%)$ was obtained with strain ATCC 26602 . Xylose was converted nearly stoichiometrically to xylitol by all strains tested (Table 1). S. cerevisiae ATCC 26603 utilized $31 \%$ of the xylose in the substrate mixture, which is considerably greater than reported previously for this strain (Gong et al., 1983).

\section{Effect of medium composition and oxygen on D-xylose utilization by S. cerevisiae ATCC 26602}

$S$. cerevisiae ATCC 26602 failed to utilize D-xylose as the sole carbon source in liquid YNB medium and did not grow on agar plates containing D-xylose and YNB (Table 2; Fig. 1). Utilization of xylose, however, occurred in the presence of sugars (Table 2), polyols (Table 2), organic acids (Table 3 ) or ethanol (Table 3). The rate of xylose utilization was very slow. The specific rate of xylose utilization in the presence of D-xylose, D-raffinose, D-glucose, glycerol and D-ribose was $0.007 \mathrm{~h}^{-1}$. (Obtained by dividing the overall volumetric rate of xylose utilization by the final biomass concentration.) The biomass in the sugar mixture increased from an initial value of $0.06 \mathrm{~g} \mathrm{l}^{-1}$ to $2.70 \mathrm{~g} \mathrm{l}^{-1}$ within $7 \mathrm{~d}$. In the presence of D-ribose $69 \%$ of the xylose was utilized within $7 \mathrm{~d}$ (Table 2). Furthermore, xylose and ribose were utilized simultaneously in shake-flasks (Fig. 1) with the concomitant production of xylitol. Under aerobic conditions no ethanol production was detected. Growth on the co-substrate was not a prerequisite for xylose utilization. Although $S$. cerevisiae is described in the taxonomic literature as unable to assimilate D-ribose (Barnett et al., 1983), strain ATCC 26602 utilized $42 \%$ of the D-ribose as sole carbon source (Table 2) without growth. The absence or presence of growth on the sugar and polyol substrates was in accordance with the classical description of $S$. cerevisiae by Kreger-van Rij (1984) and Barnett et al. (1983).

Xylose was utilized in the absence of another substrate in YEP medium (Table 4). Yeast extract appeared to be the most important component stimulating xylose utilization since xylose was not utilized in a medium containing only peptone and salts. The addition of glutamic acid to

\section{Table 1. Utilization of D-xylose in a substrate mixture}

The $S$. cerevisiae strains listed were incubated in D-xylose $\left(10 \mathrm{~g} \mathrm{t}^{-1}\right)$ and YNB medium in the presence or absence of $10 \mathrm{~g} \mathrm{l}^{-1}$ each of D-raffinose, D-glucose, glycerol and D-ribose in $100 \mathrm{ml}$ shake-flasks for $6 \mathrm{~d}$ at $30{ }^{\circ} \mathrm{C}$ under aerobic conditions. Values are means of three replicates; standard coefficients of variation were less than $10 \%$ of the means. In the absence of the substrate mixture no xylose was utilized.

\begin{tabular}{|c|c|c|}
\hline \multirow[b]{2}{*}{ Strain } & \multicolumn{2}{|c|}{ Mixture present } \\
\hline & $\begin{array}{c}\text { Xylose } \\
\text { utilized } \\
\left(\mathrm{g} \mathrm{l}^{-1}\right)\end{array}$ & $\begin{array}{c}\text { Xylitol } \\
\text { formed } \\
\left(\mathrm{g} \mathrm{l}^{-1}\right)\end{array}$ \\
\hline ATCC 26602 & $7 \cdot 4$ & $7 \cdot 8$ \\
\hline ATCC 26603 & $3 \cdot 1$ & $3 \cdot 3$ \\
\hline CBS 1907 & $5 \cdot 7$ & $6 \cdot 6$ \\
\hline CSIR-Y2 & 3.9 & $4 \cdot 2$ \\
\hline
\end{tabular}


Table 2. Substrate utilization and xylitol formation by S. cerevisiae ATCC 26602

The yeast was incubated in YNB medium plus substrate(s) indicated in test-tubes for $7 \mathrm{~d}$ at $30^{\circ} \mathrm{C}$ under aerobic conditions. Values in parentheses are SDs of three determinations. ND, Not determined; NA, not applicable.

\section{Substrate combination (each $5 \mathrm{~g} \mathrm{l}^{-1}$ )}

D-Xylose, raffinose,

D-Glucose, glycerol,

D-Ribose

D-Xylose, raffinose

D-Xylose, D-glucose

D-Xylose, D-ribose

D-Xylose, D-galactose

D-Xylose, L-arabinose

D-Xylose, glycerol

D-Xylose, ribitol

(adonitol)

D-Xylose

Raffinose

D-Glucose

D-Ribose

D-Galactose

L-Arabinose

Glycerol

Ribitol (adonitol)
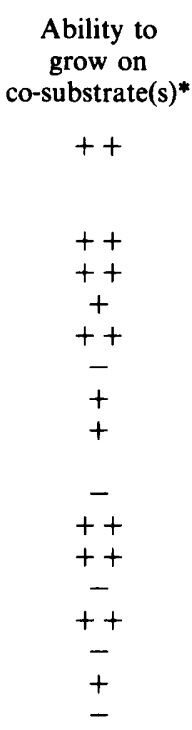

\author{
Xylose \\ $(\%)$
}

$74(1 \cdot 8)$

32

$37(2 \cdot 9)$

$69(0.6)$

$31(2 \cdot 2)$

$2(3 \cdot 9)$

$34(0.6)$

$7(0.9)$

0

NA
NA
NA
NA
NA
NA
NA

Ratio xylitol
produced/xylose
utilized

0.91

0.83

0.95

0.88

$1 \cdot 25$

1.00

1.00

0.75

0

\section{NA}

NA

NA

NA

NA

NA

NA

\begin{tabular}{|c|}
\hline $\begin{array}{c}\text { Co-substrat } \\
\text { utilized } \\
(\%)\end{array}$ \\
\hline $60 \dagger$ \\
\hline ND $\ddagger$ \\
\hline $100(0)$ \\
\hline $55(0.8)$ \\
\hline ND§ \\
\hline 0 \\
\hline $46(0 \cdot 1)$ \\
\hline 0 \\
\hline NA \\
\hline NDł \\
\hline $100(0)$ \\
\hline $42(0.4)$ \\
\hline $\begin{array}{c}\text { ND } \\
35(1 \cdot 3)\end{array}$ \\
\hline $\begin{array}{c}71(3.6) \\
0\end{array}$ \\
\hline
\end{tabular}

${ }^{*}$ Growth on agar plates: ++ , growth after $1 \mathrm{~d} ;+$, growth after $7 \mathrm{~d}$; - , no growth after $14 \mathrm{~d}$.

$\dagger$ Raffinose was not determined and from the $60 \%$ of the other substrates utilized, $100 \%$ glucose, $34 \pm 3 \%$ ribose and $46 \pm 3 \%$ glycerol were utilized.

$\ddagger$ Raffinose was converted to melibiose, but the amounts were not quantified.

$\S$ Galactose could not be separated from xylose by HPLC and $100 \%$ utilization was assumed in order to calculate the amount of xylose utilized.

Table 3. Xylose utilization and xylitol formation by S. cerevisiae ATCC 26602

The yeast was incubated in YNB medium plus organic acids and ethanol as indicated in test-tubes for $7 \mathrm{~d}$ at $30^{\circ} \mathrm{C}$ under aerobic conditions. Values in parentheses are SDs of three determinations. ND, Not determined; NA, not applicable.

$$
\begin{gathered}
\text { Substrate } \\
\text { combination } \\
\text { (each } 5 \mathrm{~g}^{-1} \text { ) }
\end{gathered}
$$

D-Xylose, acetate D-Xylose, citrate D-Xylose, gluconate D-Xylose, glyoxylate D-Xylose, pyruvate D-Xylose, ethanol

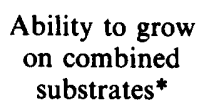

$$
\begin{gathered}
++ \\
+ \\
+ \\
\text { ND } \\
++ \\
++
\end{gathered}
$$

$$
\begin{gathered}
\text { Xylose } \\
\text { utilized } \\
(\%)
\end{gathered}
$$$$
10
$$$$
10(4 \cdot 0)
$$$$
0
$$$$
0
$$$$
10(0 \cdot 1)
$$

$21(1.5)$
Ratio xylitol produced/xylose utilized

$$
\begin{gathered}
0.80 \\
0.40 \\
\text { NA } \\
\text { NA } \\
0.80 \\
1.27
\end{gathered}
$$

* Growth on agar plates: ++ , growth after $3 \mathrm{~d} ;+$, growth after $7 \mathrm{~d} ;-$, no growth after $14 \mathrm{~d}$.

YNB containing xylose and ribose increased the amount of xylose utilized suggesting a role in promoting xylose utilization (Table 4).

D-Xylose was not fermented when supplied as the sole carbon source under anaerobic conditions. In the presence of D-ribose, however, $53 \%$ of the xylose was utilized and stoichiometrically converted to xylitol within 4 weeks, while $82 \%$ of the ribose was utilized and $1.2 \mathrm{~g}$ ethanol $1^{-1}$ was produced (Table 5). Ribose was also utilized as sole carbon source under anaerobic conditions with the production of $0.9 \mathrm{~g}$ ethanol $1^{-1}$. 
Table 4. Effect of medium, composition on xylose utilization by S. cerevisiae ATCC 26602 in the presence or absence of ribose

The yeast was incubated in $5 \mathrm{ml}$ of the stated medium in test-tubes for $7 \mathrm{~d}$ at $30^{\circ} \mathrm{C}$ under aerobic conditions. Values in parentheses are SDs of three determinations. ND, Not determined; NA, not applicable.

\begin{tabular}{|c|c|c|c|c|c|}
\hline \multirow[b]{2}{*}{ Medium } & \multicolumn{2}{|c|}{ Xylose alone $\left(5 \mathrm{~g} \mathrm{l}^{-1}\right)$} & \multicolumn{3}{|c|}{ Xylose + ribose $\left(\right.$ each $\left.5 \mathrm{~g} \mathrm{l}^{-1}\right)$} \\
\hline & $\begin{array}{c}\text { Xylose } \\
\text { utilized } \\
(\%)\end{array}$ & $\begin{array}{c}\text { Ratio xylitol } \\
\text { produced/xylose } \\
\text { utilized }\end{array}$ & $\begin{array}{c}\text { Xylose } \\
\text { utilized } \\
(\%)\end{array}$ & $\begin{array}{c}\text { Ribose } \\
\text { utilized } \\
(\%)\end{array}$ & $\begin{array}{c}\text { Ratio xylitol } \\
\text { produced/xylose } \\
\text { utilized }\end{array}$ \\
\hline YNB & 0 & NA & $43(3 \cdot 5)$ & $9(1 \cdot 6)$ & $1 \cdot 20$ \\
\hline $\begin{array}{l}\text { YNB, glutamic acid } \\
\left(0.75 \mathrm{~g} \mathrm{l}^{-1}\right)\end{array}$ & ND & ND & $63(2 \cdot 1)$ & $24(2 \cdot 8)$ & $1 \cdot 17$ \\
\hline YEP & $49(2 \cdot 5)$ & $1 \cdot 05$ & 69 & 23 & 1.07 \\
\hline Half-strength YEP & $29(1.4)$ & $1 \cdot 17$ & $55(1 \cdot 2)$ & $19(1 \cdot 5)$ & $1 \cdot 12$ \\
\hline Yeast extract, salts & $49(1 \cdot 8)$ & $1 \cdot 00$ & $71(0 \cdot 3)$ & $30(1 \cdot 0)$ & 1.07 \\
\hline Yeast extract, peptone & $40(4 \cdot 6)$ & 1.06 & $70(2 \cdot 7)$ & $25(3 \cdot 1)$ & 1.04 \\
\hline Yeast extract & $41(0 \cdot 7)$ & $1 \cdot 24$ & ND & ND & ND \\
\hline Peptone, salts & 0 & NA & $35(2 \cdot 5)$ & $10(3 \cdot 9)$ & $1 \cdot 20$ \\
\hline Peptone & 0 & NA & 36 & 9 & 1.06 \\
\hline
\end{tabular}

Table 5. Sugar utilization and product formation by S. cerevisiae ATCC 26602

The yeast was incubated in YNB medium plus substrate(s) as indicated for 4 weeks at $30^{\circ} \mathrm{C}$ under anaerobic conditions. Values in parentheses are SDS of three determinations. NA, Not applicable.

\begin{tabular}{|c|c|c|c|c|}
\hline $\begin{array}{l}\text { Substrate(s) } \\
\left(\text { each } 5 \mathrm{~g} \mathrm{1}^{-1}\right)\end{array}$ & $\begin{array}{c}\text { Xylose } \\
\text { utilized } \\
(\%)\end{array}$ & $\begin{array}{c}\text { Ratio xylitol } \\
\text { produced/xylose } \\
\text { utilized }\end{array}$ & $\begin{array}{c}\text { Utilization } \\
\text { of co-substrate } \\
(\%)\end{array}$ & $\begin{array}{c}\text { Ethanol } \\
\text { produced } \\
\left(\mathrm{g} \mathrm{l}^{-1}\right)\end{array}$ \\
\hline D-Xylose & 0 & NA & NA & 0 \\
\hline D-Ribose & NA & NA & $72(1 \cdot 0)$ & $0.9(0.20)$ \\
\hline D-Xylose, D-ribose & $53(3 \cdot 3)$ & 1.00 & $82(1.0)$ & $1.2(0.08)$ \\
\hline D-Xylose, D-glucose & $14(2 \cdot 0)$ & 1.00 & $100(0)$ & $1.5(0.08)$ \\
\hline D-Glucose & NA & NA & $100(0)$ & $1.9(0.12)$ \\
\hline
\end{tabular}

Table 6. Distribution of radioactivity between metabolic products produced from $\mathrm{D}-\left[{ }^{14} \mathrm{C}\right]$ xylose by S. cerevisiae ATCC 26602

The yeast was incubated in YNB medium containing D-ribose $\left(5 \mathrm{~g} \mathrm{l}^{-1}\right)$ and $\left.\mathrm{D}-{ }^{14} \mathrm{C}\right] \mathrm{xylose}\left(5 \mathrm{~g} \mathrm{l}^{-1}\right)$ for $3 \mathrm{~d}$ at $30{ }^{\circ} \mathrm{C}$ under aerobic conditions. Of the total $\mathrm{D}$-xylose and D-ribose, $21 \cdot 8 \pm 3 \cdot 3 \%$ and $6.0 \pm 3 \cdot 1 \%$ respectively, were utilized (mean of three experiments \pm SD).

Metabolic product

Xylitol
$\mathrm{CO}_{2}{ }^{*}$
Biomass $\dagger$
Other products
Total radioactivity recovered

Radioactivity (\%)

$$
\begin{aligned}
& 91 \cdot 3 \pm 0.8 \\
& 2.6 \pm 2.3 \\
& 1 \cdot 7 \pm 0.6 \\
& 0 \\
& 95.6 \pm 2 \cdot 1
\end{aligned}
$$

* Control experiments show contamination of the $\mathrm{KOH}$ accounted for not more than $16 \%$ of the radioactivity associated with $\mathrm{CO}_{2}$.

+ Control experiments with autoclaved cells showed that not more than $25 \%$ of the radioactivity could originate from non-specific binding of labelled xylose or xylitol to the biomass.

\section{Fate of $\mathrm{D}-\left[{ }^{14} \mathrm{C}\right]$ xylose under aerobic and anaerobic conditions}

HPLC analyses indicated that there was an approximate stoichiometric conversion of xylose to xylitol (Tables 2 to 5). This was confirmed by an aerobic labelled-xylose experiment in which $91 \%$ of the ${ }^{14} \mathrm{C}$ was converted to xylitol (Table 6). No other metabolic products were found in the medium (Fig. 2). Small amounts of radioactivity were detected in $\mathrm{CO}_{2}$ and biomass (Table 6) 


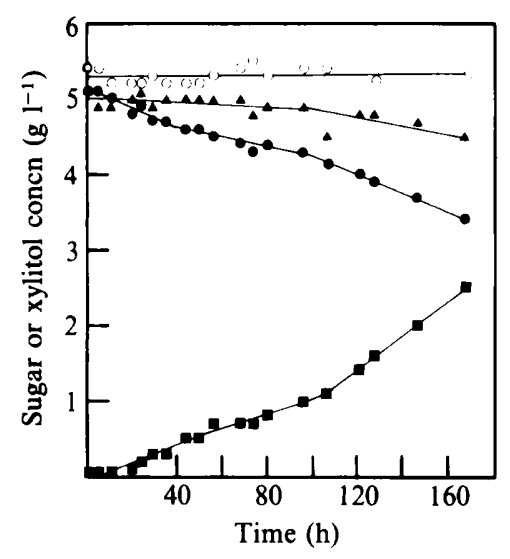

Fig. 1

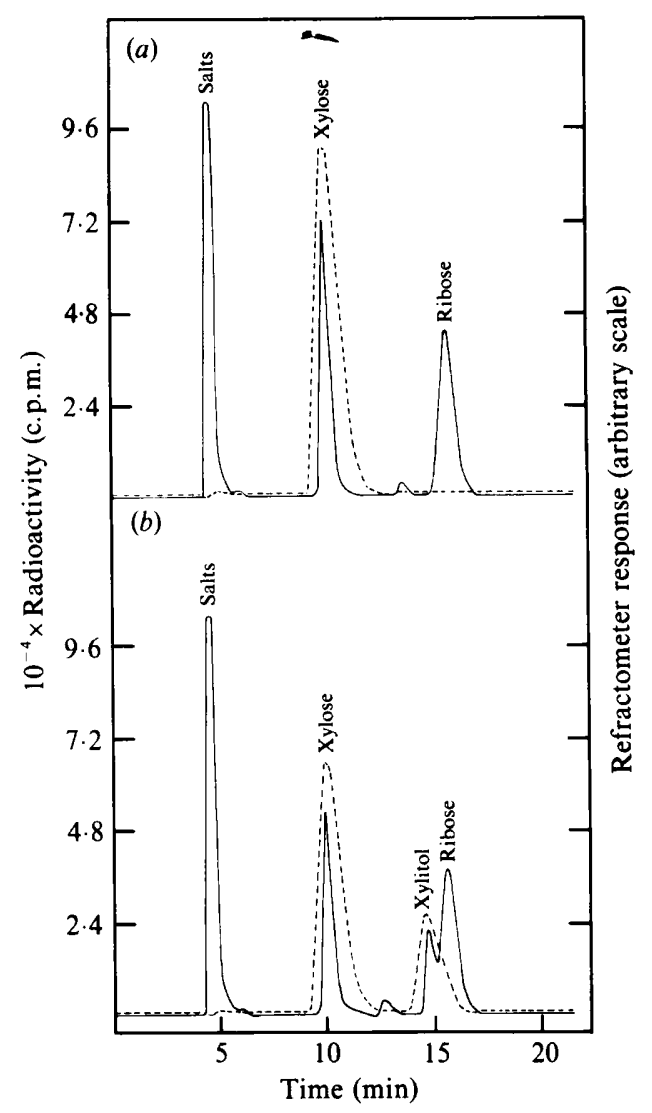

Fig. 2

Fig. 1. Aerobic utilization of $5 \mathrm{~g} \mathrm{D}$-xylose $\mathrm{l}^{-1}$ in shake-flasks in the presence $(0)$ or absence $(0)$ of $5 \mathrm{~g}$ D-ribose $1^{-1}$ by $S$. cerevisiae ATCC 26602 at $30^{\circ} \mathrm{C}$. A, D-Ribose utilization;, xylitol production. Each data point represents the mean of triplicate experiments.

Fig. 2. HPLC of medium components immediately following inoculation with $S$. cerevisiae ATCC $26602(a)$ and after incubation for $3 \mathrm{~d}(b)$ at $30^{\circ} \mathrm{C}$ under aerobic conditions in YNB medium containing $\left[{ }^{14} \mathrm{C}\right] x y l o s e\left(5 \mathrm{~g} \mathrm{l}^{-1}\right)$ and unlabelled D-ribose $\left(5 \mathrm{~g} \mathrm{l}^{-1}\right) .-$, Refractometer response; ---, radioactivity.

which suggests that xylose may be metabolized beyond xylitol. Similarly, $92 \%$ of the labelled xylose $\left(5 \mathrm{~g} \mathrm{l}^{-1}\right)$ was converted to xylitol under anaerobic conditions in the presence of ribose $\left(5 \mathrm{~g} \mathrm{l}^{-1}\right)$ while only $0.66 \pm 0.17 \%$ and $0.12 \pm 0.17 \%$ were incorporated into biomass and $\mathrm{CO}_{2}$ respectively. No significant levels of other ${ }^{14} \mathrm{C}$-labelled metabolites such as ethanol were detected, indicating that $S$. cerevisiae failed to produce ethanol from xylose (results not shown).

\section{DISCUSSION}

The results presented here show that several strains of $S$. cerevisiae are unable to grow on xylose as sole carbon source but can convert most of the xylose to xylitol when another substrate is co-metabolized. Previously, xylose utilization has been reported in combination with other substrates including D-glucose and xylitol (Hsiao et al., 1982) as well as D-galactose (Batt et al., 1986). However, our studies show that a greater degree of xylose utilization could be achieved in combination with certain substrates such as D-ribose. The most extensive utilization of xylose occurred in combination with some sugars, ethanol or glycerol while xylose was utilized poorly or not at all in the presence of Krebs cycle intermediates, ribitol and L-arabinose. 
Gong et al. (1983) found that S. cererisiae ATCC 26603 utilized only $1.04 \%$ of $50 \mathrm{~g}$ xylose $\mathrm{I}^{-1}$ aerobically and $0.51 \%$ fermentatively when xylose was present as the sole substrate in a yeast extract/malt/peptone medium and that xylitol was the main metabolic product. However, the incubation time used was shorter $(3 \mathrm{~d})$ and the initial biomass concentration was not specified. The initiation of xylose utilization by yeast extract may be explained by the fact that yeast extract contains carbohydrates (Bridson \& Brecker, 1970) and the detection of a peak compatible with ribose by HPLC in the batch of yeast extract used in this study (data not shown). Likewise, Quain \& Boulton (1987) found that YEP medium but not YNB supported growth of $S$. cerevisiae on mannitol, another substrate on which growth of $S$. cerevisiae was reported either not to occur or to occur after a delay of 14 to $21 \mathrm{~d}$ (Barnett et al., 1983).

The mechanism of stimulation of xylose utilization by the co-substrates is unknown. The uptake system is probably not the site of stimulation. Xylose is taken up by the general monosaccharide transport system in $S$. cerevisiae at a rate approximately tenfold faster than the rate of utilization observed in this study (Cirillo, 1968). The co-substrate is also unlikely to be involved in the induction of XR since xylose utilization starts immediately in mixtures of xylose and ribose. Morever, XR does not appear to be repressed by glucose since xylose utilization was observed without a delay when glucose-grown cells were transferred to medium containing xylose and ribose. Furthermore, xylose was utilized at similar rates in the presence of co-substrates ranging from sugars to ethanol. These results suggest that XR may be constitutive in our strain of $S$. cerevisiae in contrast to a report stating that it is inducible in another strain (Batt et al., 1986). This enzyme has a broad substrate specificity in a number of organisms including yeasts (International Union of Biochemistry, 1979; Bolen \& Detroy, 1985; Verduyn et $a l ., 1985)$ and is present when Pachysolen tannophilus is grown on substrates other than xylose (Bolen \& Detroy, 1985). Non-specific reduction of xylose by an enzyme induced by another carbon source can therefore not be excluded as a possible mechanism for the conversion of xylose to xylitol by $S$. cerevisiae. For example, transketolase isolated from spinach acted on xylose although at a rate considerably slower than on the natural substrate (Villafranca \& Alexrod, 1971).

The presence of XR and XD in S. cerevisiae (Batt et al., 1986) would permit the conversion of intracellular xylose to xylulose. The conversion of $\left[{ }^{14} \mathrm{C}\right]$ xylose into mainly xylitol with only minor amounts being incorporated into biomass and $\mathrm{CO}_{2}$ under aerobic and anaerobic conditions suggests that although a pathway does exist to assimilate xylose, the rate-limiting step is the conversion of xylitol to xylulose. In yeasts such as Candida utilis, XR has a specific requirement for $\mathrm{NADPH}_{2}$ whereas XD requires $\mathrm{NAD}^{+}$(Bruinenberg et al., 1984). Under anaerobic conditions co-factor imbalance occurs as $\mathrm{NADH}_{2}$ cannot be re-oxidized and fermentation does not take place. However, yeasts possessing an $\mathrm{NADH}_{2}$-specific XR circumvent this co-factor imbalance and are able to ferment xylose anaerobically (Bruinenberg et al., 1984). The co-factor requirements of these two initial steps in $S$. cerevisiae are poorly understood although Batt et al. (1986) reported that $\mathrm{XR}$ and $\mathrm{XD}$ use $\mathrm{NADPH}_{2}$ and $\mathrm{NAD}^{+}$respectively. A similar imbalance may occur in $S$. cerevisiae as indicated by the accumulation of xylitol in this yeast. It is, however, unclear why $\mathrm{NADH}_{2}$ could not be re-oxidized under aerobic conditions, if its accumulation is limiting the conversion of xylitol to xylulose.

Why ribose should promote the utilization of xylose to a greater degree than other substrates remains unclear. Ribose could possibly be transported into the cell via the general monosaccharide transport system (Maxwell \& Spoerl, 1971) and be substantially metabolized as no metabolic intermediates such as ribitol were detected in the culture medium and ethanol accumulated under anaerobic conditions. This process could yield co-factors involved in xylose utilization. However, this requires further investigation.

We thank T. Pearson, Anita de Necker and P. J. Botes for technical assistance and Carol Viljoen for excellent typing. J. P. Mildenhall is thanked for suggesting improvements to the manuscript. Financial assistance from the Foundation for Research Development and the Central Research Fund of the University of the Orange Free State is gratefully acknowledged. 


\section{REFERENCES}

Barnett, J. A., Payne, R. W. \& Yarrow, D. (1983). Yeasts: Characteristics and Identification. Cambridge \& New York: Cambridge University Press.

Batt, C. A., Carvallo, S., Easson, D. D., Akedo, M. \& SinskeY, A. J. (1986). Direct evidence for a xylose metabolic pathway in Saccharomyces cerevisiae. Biotechnology and Bioengineering 28, 549-553.

Bolen, P. L. \& Detroy, R. W. (1985). Induction of NADPH-linked D-xylose reductase and NADlinked xylitol dehydrogenase activities in Pachysolen tannophilus by D-xylose, L-arabinose, or D-galactose. Biotechnology and Bioengineering 17, 302-307.

Bridson, E. Y. \& Brecker, A. (1970). Design and formulation of microbial culture media. Methods in Microbiology 3B, 229-295.

BruinenberG, P. M., De Bot, P. H. M., van DiJken, J. P. \& Scheffers, W. A. (1984). NADH-linked aldose reductase: the key to anaerobic alcoholic fermentation of xylose by yeasts. Applied Microbiology and Biotechnology 19, 256-260.

CIRILlo, V. P. (1968). Relationship between sugar structure and competition for the sugar transport system in baker's yeast. Journal of Bacteriology 95, 603-611.

D'Amore, T., Panchal, C. J. \& Stewart, G. G. (1988). Intracellular ethanol accumulation in Saccharomyces cerevisiae during fermentation. Applied and Environmental Microbiology 54, 110-114.

Gong, C.-S., Chen, L.-F., Flickinger, M. C., Chiang, L.-C. \& Tsao, G. T. (1981). Production of ethanol from $\mathrm{D}$-xylose by using $\mathrm{D}$-xylose isomerase and yeasts. Applied and Environmental Microbiology 41, 430-436.

Gong, C.-S., Claypool, T. A., McCracken, L. D., Maun, C. M., Ueng, P. P. \& TSAO, G. T. (1983). Conversion of pentoses by yeasts. Biotechnology and Bioengineering 25, 85-102.

Hsiao, H.-Y., Chiang, L.-C., Ueng, P. P. \& Tsao, G. T. (1982). Sequential utilization of mixed monosaccharides by yeasts. Applied and Environmental Microbiology 43, 840-845.

Hungate, R. E. (1969). A roll tube method for cultivation of strict anaerobes. Methods in Microbiology 3B, 117-132.

INTERNATIONAL UNION OF BIOCHEMISTRY (1979). Nomenclature Committee Recommendations. In Enzyme Nomenclature, pp. 32-33. New York: Academic Press.

Kleinzeller, A. \& KotYK, A. (1967). Transport of monosaccharides in yeast cells and its relationship to cell metabolism. In Aspects of Yeast Metabolism, pp. 33-45. Edited by A. K. Mills \& H. Krebs. Philadelphia: F. A. Davis.
Kock, J. F. L., Lategan, P. M., Botes, P. J. \& VILJOEN, B. C. (1985). Developing a rapid statistical identification process for different yeast species. Journal of Microbiological Methods 4, 147-154.

KoTYK, A. (1967). Properties of the sugar carrier in baker's yeast. II. Specificity of transport. Folia microbiologica 12, 121-131.

KREGER-VAN RIJ, N. J. W. (1984). The Yeasts: a Taxonomic Study, 3rd edn, pp. 45-104 \& 384. Amsterdam: Elsevier Science Publishers.

MaXWell, W. A. \& SPOERL, E. (1971). Mannitol uptake by Saccharomyces cerevisiae. Journal of Bacteriology 105, 753-758.

DU Preez, J. C. \& Prior, B. A. (1985). A quantitative screening of some xylose-fermenting yeast isolates. Biotechnology Letters 7, 241-246.

du Preez, J. C., Bosch, M. \& Prior, B. A. (1987). Temperature profiles of growth and ethanol tolerance of the xylose-fermenting yeasts Candida shehatae and Pichia stipitis. Applied Microbiology and Biotechnology 25, 521-525.

Quain, D. E. \& Boulton, C. A. (1987). Growth and metabolism of mannitol by strains of Saccharomyces cerevisiae. Journal of General Microbiology 133, 1675-1684.

Ueng, P. P., Hunter, C. A., Gong, C.-S. \& Tsao, G. T. (1981). D-Xylulose fermentation in yeasts. Biotechnology Letters 3, 315-320.

Verduyn, C., van Kleef, R., Frank, J., Schreuder, H., van Dijken, J. P. \& Scheffers, W. A. (1985). Properties of the $\mathrm{NAD}(\mathrm{P}) \mathrm{H}$-dependent xylose reductase from the xylose-fermenting yeast Pichia stipitis. Biochemical Journal 226, 669-677.

Villafranca, J. J. \& AXelrod, B. (1971). Heptulose synthesis from nonphosphorylated aldoses and ketoses by spinach transketolase. Journal of Biological Chemistry 246, 3126-3131.

Watson, N. E., Prior, B. A., Du Preez, J. C. \& LATEGaN, P. M. (1984a). Oxygen requirements for D-xylose fermentation to ethanol and polyols by Pachysolen tannophilus. Enzyme and Microbial Technology 6, 447-450.

Watson, N. E., Prior, B. A., Lategan, P. M. \& Lussi, M. (1984b). Factors in acid treated bagasse inhibiting ethanol production from D-xylose by Pachysolen tannophilus. Enzyme and Microbial Technology 6, 451-456.

WICKERHAM, L. J. (1951). Taxonomy of Yeasts, Technical Bulletin no. 1029, United States Department of Agriculture. 